\title{
Labour as a knowledge carrier: how increased mobility influences entrepreneurship
}

\author{
Pontus Braunerhjelm ${ }^{1,2} \cdot$ Ding Ding ${ }^{1}$ Per Thulin ${ }^{1,2}$
}

(C) Springer Science+Business Media New York 2015

\begin{abstract}
According to the knowledge-based spillover theory of entrepreneurship (KSTE), entrepreneurship is positively associated with the knowledge endowment level. An increase in knowledge expands the opportunity set, which is then exploited by heterogeneous entrepreneurs. The objective of this paper is to empirically test the validity of the KSTE by employing a detailed database comprising more than 19 million observations for the period 2001-2008 at the level of individuals, firms and regions in Sweden. Knowledge is claimed to be partly embodied in labour, implying that an increase in labour mobility can be expected to influence knowledge endowment at the regional level. Our dependent variable is an individual who has remained in a region throughout the time period considered. Controlling for a number of other variables, inter-regional labour inflows and intra-regional mobility levels are shown to exert a strong positive effect on entrepreneurship. This contrasts with inter-regional outflows, which negatively affect entrepreneurial entry. Another noteworthy result is that the probability of exploiting an increased knowledge stock through entrepreneurship increases by $15 \%$ points if the individual has previous experience in starting a firm.
\end{abstract}

Keywords Entrepreneurship - Knowledge-based spillover theory of entrepreneurship Knowledge diffusion · Labour mobility

JEL Classification $\mathrm{J} 61 \cdot \mathrm{L} 26 \cdot \mathrm{O} 33$

Pontus Braunerhjelm

pontus.braunerhjelm@indek.kth.se

1 Division of Entrepreneurship and Innovation, INDEK, KTH Royal Institute of Technology, 10044 Stockholm, Sweden

2 Swedish Entrepreneurship Forum, Grevgatan 34, 11453 Stockholm, Sweden 


\section{Introduction}

Entrepreneurship is increasingly acknowledged as key to economic growth and increased prosperity. ${ }^{1}$ It contributes to competition, innovation and employment opportunities, thereby influencing the dynamics and functioning of market economies. This may seem obvious, or even banal, but only 20-30 years ago, it was far from evident. The building blocks of growth were then still supposed to be capital investments, labour, human capital and a more general and elusive knowledge factor (Solow 1957; Swan 1956). More recent contributions herald knowledge, i.e., education and R\&D, as the main driver of growth although in exactly what way and through which mechanisms remain unclear (Romer 1986, 1990; Lucas 1988; Aghion and Howitt 1992; Aghion et al. 2013). For instance, the Romer type of growth models simply assumed geographically unbounded knowledge spillovers to take place, whereas the neo-Schumpeterian models capture a quite extreme type of high-performing, R\&D-based firms/entrepreneurs, in which the winner takes all. This appears to be the exception rather than capturing the typical entrepreneur.

Thus, despite considerable progress in modelling growth, the origin of the growthpromoting agent - the entrepreneur-was poorly conceived. In the early 2000s, Zoltan Acs, David Audretsch, Pontus Braunerhjelm and Bo Carlsson set out to remedy that potentially important gap in previous models. ${ }^{2}$ The first versions of the knowledge-based spillover theory of entrepreneurship (KSTE) appeared in a series of working papers in $2003 / 2004$, whereas a more comprehensive model was presented some years later (Acs et al. 2009). The building blocks of the KSTE are (1) societal investments in knowledge, i.e., the existing knowledge stock at a given point in time, (2) how efficient the economy is in converting knowledge into societal useful goods, i.e., the design of the institutional setup (the knowledge filter), and (3) individual entrepreneurial ability. ${ }^{3}$

In the KSTE entrepreneurs are assumed to employ their individual-specific abilities to exploit the existing stock of knowledge (new and old) in order to create new products to be tested at, and selected by, the market. While knowledge becomes the prime source of entry, entrepreneurship is the vehicle required to generate knowledge spillovers that takes the form of new goods and services (Audrestch and Kielbach 2007; Braunerhjelm et al. 2010; Qian and Acs 2013). Hence, the question concerning the origin of entrepreneurial opportunities, which is widely discussed in the literature but lacks consensus (Shane and Venkataraman 2000), is identified as knowledge endowments. The elegant feature of the KSTE is that it bridges the endogenous growth theories with a solid explanation of the emergence of entrepreneurial opportunity. The microeconomic foundation of growth thus becomes much more distinct (Bruton et al. 2010; Audretsch et al. 2012; Acs and Sanders 2013; Audretsch and Belitski 2013; Stam 2013). ${ }^{4}$ Similarly, the institutional setup, or what is denoted the knowledge filter in the KSTE, is allotted a distinctive role related to entrepreneurship in transforming knowledge into societal utility (Block et al. 2013).

\footnotetext{
1 Several studies confirm a positive relationship between new firm formation, productivity and economic growth [for surveys see e.g. Van Praag and Versloot (2007), Karlsson and Nyström (2008), Braunerhjelm (2011)].

2 In 2002 the research project "Entrepreneurship and Society", headed by Pontus Braunerhjelm and mainly involving Zoltan Acs, David Audretsch and Bo Carlsson, was granted generous financial support from Marianne and Marcus Wallenberg's Foundation.

3 For a recent review of the KSTE, see Ghio et al. (2015).

4 The link to Schumpeter is obvious; he viewed the creation of technological opportunity as essentially lying outside the domain of the entrepreneur. Rather, the identification and exploitation of such opportunities is what distinguishes entrepreneurs, i.e., innovation.
} 
Knowledge comes in different forms and may be accumulated in different ways (Audretsch 2007; Carlsson et al. 2009; Acosta et al. 2011; Acs and Sanders 2012; Steuzer et al. 2014). Knowledge production has predominantly been attributed to universities, public research institutes and private companies due to their R\&D investments. Another conceivable mechanism to augment and diffuse knowledge would be labour mobility. That follows from two observations previously made in the literature. First, knowledge has been shown to be partly tacit and embodied in individuals, i.e., it cannot be easily codified or transmitted between individuals, firms or regions (Polanyi 1966; von Hippel 1988; Audretsch and Lehmann 2005). Second, knowledge seems to be lumpy, i.e., it is confined to certain regions or contained in clusters such as Silicon Valley (Plummer and Acs 2014).

Given these specific features of knowledge, its diffusion can then either be substantiated by firms relocating to previously agglomerated areas (bringing firm-specific knowledge and combining it with localized knowledge) or through labour mobility, whereby individual-specific knowledge can be utilized in other firms and regions. Both processes are likely to enlarge the knowledge base and expand the opportunity space for potential new entrepreneurs. By becoming carriers of partly tacit knowledge, labour mobility can be expected to induce innovative and entrepreneurial activities. However, the extent to which this is the case will vary with individuals' capacity to coordinate new knowledge and their knowledge acquisition efficiency (Qian and Acs 2013). In the words of Schumpeter: "Whatever the type, everyone is an entrepreneur only when he actually carries out new combinations and loses that character as soon as he has built up his business, when he settles down to running it as other people run their business" (Schumpeter 1911/1934, p. 78).

By employing an extensive and detailed micro-level dataset at the level of individuals, firms and regions in Sweden for the period 2001-2008, we will empirically test how knowledge flows embodied in labour affect entrepreneurship. Our dependent variable is an individual who has remained within the region throughout the period we consider. While controlling for a large number of variables related to the individual and regional levels, we provide new evidence regarding the impact of knowledge flows on entrepreneurship. First, inter-regional inflows of labour, as well as intra-regional levels of mobility, are shown to have a strong positive and significant effect on regional entrepreneurship. Second, interregional labour outflows are, by contrast, shown to negatively impact entrepreneurship, suggesting that both direct (loss of knowledge) and indirect effects (knowledge networks) tend to weaken the knowledge base, thereby having a detrimental effect on new ventures.

By focusing on the role of labour mobility as carriers of knowledge we hence extend previous findings where knowledge diffusion had primarily been related to the presence of universities, aggregated R\&D-stocks or the level of patenting. ${ }^{5}$ The policy implications are obvious and seem highly relevant for regions and countries that are searching for growth inducing policies: dismantling barriers to labour mobility and thereby making the knowledge filter more permeable would enhance the likelihood of higher growth.

The remainder of the paper is organized as follows. We first refer to previous research relevant to the current study in Sect. 2, focusing on knowledge and labour mobility. In Sect. 3, we present the data and empirical method, followed by the results of the regression

\footnotetext{
5 A specific type of labour mobility that has fostered new ventures is when an employee leaves a firm to start a new one, i.e., a spin-off (see e.g. Criaco et al. 2014; Karnani 2013; Baltzopoulos et al. 2015). That has been widely studied in the previous literature but is radically different from the issue addressed in the present study which refers to labour mobility, knowledge flows and entrepreneurship.
} 
analysis in Sect. 4. A summary of the findings and policy consequences concludes the paper in Sect. 5.

\section{Previous research}

Knowledge is a multi-faceted concept and lends itself to a number of different definitions: an object, a process, a stock or a flow (Carlsson et al. 2009). Alternatively, knowledge is characterized by its origin, i.e., scientific, technological or entrepreneurial. For our purpose, the most relevant aspects of knowledge refer to its distribution and diffusion. Hayek (1945) had already concluded that a key feature of a market economy is the distribution of knowledge across a large number of heterogeneous individuals. This implies that divergence in the valuation of new ideas across economic agents, or between economic agents and decision-making hierarchies of incumbent enterprises, seems likely. Variety related to knowledge, or the interpretation of knowledge, combined with selection through market processes can be expected to constitute a fundamental source of entrepreneurial opportunity. In addition, such variety would also foster a market structure dominated by imperfect information and imperfect competition.

Schumpeter also realized that new insights-knowledge-were instrumental in promoting entrepreneurial dynamics, i.e., creative destruction, and he described it in the following way: it "[I]ncessantly revolutionizes the economic structure from within, incessantly destroying the old one, incessantly creating a new one" (Schumpeter 1942, p. 83). However, Schumpeter was never explicit about the role of knowledge. Rather, knowledge was exploited as individuals exercised their combinatorial capacities.

Note that even though education can be expected to be a dominant component of a society's knowledge stock and a crucial determinant of creative destruction and growth, it is not necessarily a good predictor of entrepreneurship. Knowledge refers to more than average years of schooling, not least experience and on the job learning. The empirical evidence are ambiguous, the impact of education varies from positive to negative or insignificant (Berglann et al. 2009; Braunerhjelm et al. 2010). The reasons are attributed different entry barriers across industries, increased employability with higher education and what type of entrepreneurship that is analysed (opportunity- or necessity-based). The number of new hairdressers is substantially higher than the entry of biotechnology firms or steel mills.

What labour mobility contributes with is a host of new and diversified knowledge that can be expected to enlarge the opportunity set for entrepreneurs as they exploit their combinatorial abilities to draw upon that knowledge and set up a new firm, not necessarily related to the level of education.

A further distinctive feature of knowledge, which has been acknowledged for at least a century, concerns its geographical localization. Knowledge tends to be unevenly distributed and concentrated in certain areas and regions. Moreover, knowledge tends to be sticky and not easily transmitted to other locations, or even between firms. Hence, the decision to localize in knowledge-intense areas is rational because it facilitates knowledge spillovers, partly through labour mobility (Koo and Cho 2011; Lasch et al. 2013). This is also confirmed in previous studies. In particular, proximity to research centres, universities and "stars" seems to encourage innovative and qualitative entrepreneurship (Audretsch and Stephan 1999; Zucker et al. 1998; Shane 2001; Breznits and Feldman 2012; Fritsch and Aamoucke 2013). Given that knowledge contains both codifiable and tacit elements 
(Polanyi 1966), face-to-face interactions become necessary in conveying complex and complicated issues (von Hippel 1988). ${ }^{6}$

Another dimension of labour mobility is that it may serve to strengthen knowledge diffusion through extended networks. The geographical extent of such networks has been shown to vary. Some studies have shown that these networks are spatially constrained (Batten et al. 1989; Kobayashi 1995; Owen-Smith and Powell 2006). A recent study, however, finds the opposite (Braunerhjelm et al. 2014)-inter-regional networks seem to be more important than intra-regional networks, at least for firms' innovative behaviour. Social networks can be instrumental in reducing transaction costs and in strengthening firms' innovative capacity (Williamson 1971; Hayter 2013; Kaiser et al. 2015). At the individual level, capacity differences across economic agents have been shown to derive from weaker personal, social and professional networks (Birley 1985; Aldrich and Zimmer 1986; Szarka 1990). Therefore, labour mobility can be expected to generate increased knowledge not only directly but also indirectly through extended networks.

Consequently, knowledge endowment and the functioning of the labour market are closely linked. Regulations and interventions in labour markets seem however to be the rule rather than the exception, which may have implications for entrepreneurial opportunity. In particular, labour markets tend to be divided between insiders and outsiders, whereby the former are offered stronger job protections, have greater market power and are less willing to switch between jobs or to become an entrepreneur (Lindbeck and Snower 1989). Nyström (2011) and Quimet and Zarutskie (2014) conclude that new firms are more likely to find employees among new labour market entrants, i.e., immigrants and recent graduates. Because labour markets are arenas in which the knowledge demand and supply is matched, the degree of labour market regulation influences the supply, selection and matching of entrepreneurs and employees. Just as the identification and valuation of an entrepreneurial opportunity may differ across individuals, the "... value of a given worker is likely to vary dramatically across different employers and the disutility of effort associated with work will vary for a typical worker across the firms she might work for" (Lazear and Oyer 2012). ${ }^{7}$

The level of entrepreneurship and the variation in the opportunity structure are, of course, not solely generated by individual preferences, well-functioning labour markets and knowledge endowments but ultimately depend on a whole set of formal and informal institutional factors. ${ }^{8}$ In essence, the determinants of entrepreneurship relate to variables derived from industrial organization (market structure and industry), economic geography (size, density and market potential) and individual-level characteristics (age, experience and education), some of which are cited above (Andersson and Hellerstedt 2009; Parker 2009; Wennberg et al. 2011). ${ }^{9}$ In the empirical analysis we will classify our explanatory variables on the above mentioned three main categories.

\footnotetext{
${ }^{6}$ Labour mobility may, however, have a limited effect on knowledge diffusion if individual competences have little or no value in isolation, but when combined with other competencies in an organization, it constitutes an important part of the organization's knowledge capital.

7 Sørensen and Sharkey (2014) also contended that the internal labour markets of incumbent firms are important for entrepreneurial endeavours. See also Baltzopoulos et al. (2015).

${ }^{8}$ See, for instance, De Soto (1989), Baumol (1990), North (1990), Henrekson (2005), Glaeser and Kerr (2009).

${ }^{9}$ See e.g. Van Praag and Versloot (2007) and Berglann et al. (2009) for an account of empirical support of several of these variables.
} 


\section{Hypotheses, data and empirical method}

\subsection{Three hypotheses}

Following the KSTE, we assume that individuals combine their idiosyncratic entrepreneurial talents $(e)$ with the overall knowledge stock $(K)$ to start new firms. The probability $(p)$ of finding an entrepreneurial opportunity worth pursuing can then be modelled as a function of entrepreneurial talent and the aggregate knowledge stock,

$$
p=f(e, K)
$$

where $p$ is increasing in both arguments. The knowledge stock is in turn formed by previously accumulated knowledge and newly diffused knowledge, where mobility of workers between employers and regions constitutes one main channel through which new knowledge is dispersed. The knowledge stock can formally be described as a function of factors related to the accumulation and dispersion of knowledge,

$$
K=g(M, \mathbf{X})
$$

where $M$ refers to labour mobility and vector $\mathbf{X}$ to other variables affecting the level of the knowledge stock.

Labour mobility between employers can take three different forms at the local levellabour moving into the region, labour moving out from the region and intraregional labour mobility - and it is important to distinguish between these three measures since they are likely to have different implications for the knowledge stock available for entrepreneurs. We hypothesize that knowledge is more homogenous within regions than across regions and hence, that when labour enter a region they will bring more diversified new knowledge to the receiving region than workers changing employer within a given region. However, workers changing employers within a region are more likely to maintain tighter and more frequent contacts with their former colleagues than workers who arrive from other regions. There are in other words two different effects that have bearing on the diffusion of knowledge-one direct effect stemming from labour mobility and one indirect effect due to extended social networks. We form three hypotheses based on the arguments provided above.

Hypothesis 1 Entrepreneurship is expected to be positively associated with inflows of knowledge being embodied in labour, controlling for other variables at the regional and individual levels,

$$
\frac{\partial p}{\partial I N}=\frac{\partial f}{\partial K} \frac{\partial g}{\partial I N}>0
$$

where IN denotes regional inflow of labour from other regions.

Hypothesis 2 Entrepreneurship is expected to be negatively associated with outflows of knowledge being embodied in labour, controlling for other variables at the regional and individual levels,

$$
\frac{\partial p}{\partial O U T}=\frac{\partial f}{\partial K} \frac{\partial g}{\partial O U T}<0
$$

where $O U T$ denotes regional outflow of labour to other regions. 
Hypothesis 3 Intraregional labour mobility (WITHIN) can be expected to have a larger effect on entrepreneurship than inter-regional labour mobility by generating more frequent knowledge flows through extended networks,

$$
\frac{\partial p}{\partial W I T H I N}>\frac{\partial p}{\partial I N}
$$

Hence, these three hypotheses include both direct effects (labour mobility) and indirect effects (extended networks due to mobility).

The KSTE also stresses the importance of a regulatory regime (the knowledge filter) that is conducive to entrepreneurship and knowledge diffusion. Because the empirical analysis is based on regions in Sweden, there is no need to control for regulatory differences because overwhelmingly regulations are applied at the national level. However, it should be noted that in the case of Sweden, the labour market is considered highly rigid and has a dual character. Workers on permanent contracts enjoy a high level of employment protection, whereas temporary employees essentially have no such protection. The latter type of employees constitutes a minority of the Swedish labour force (approximately 16-17\%) but accounts for 60-70\% of labour mobility (Braunerhjelm et al. 2009). That may influence the selection of individuals who transition into entrepreneurship and how the knowledge stock, measured as the regional share of employees with a tertiary education, influences regional start-ups. Hence, the expected signs of some of the controls are ambiguous.

\subsection{Data and empirical method}

We implement detailed data from a matched employer-employee dataset provided by Statistics Sweden. The dataset contains information, including age, sex, and highest completed level of education, in addition to several other variables, which enable us to track all employed individuals over time and across employers in Sweden over the period 2001-2008. Individuals are sorted into 72 labour market regions ${ }^{10}$ depending on where they work, and we monitor their mobility between employers within and across regional borders throughout the period. We exclude all observations for which the total number of employed individuals in a region is smaller than 1000 to reduce the risk of having the results distorted by a few highly volatile observations.

Examining the data, we detect a trend-wise increase in the entrepreneurship rate (measured as number of self-employed divided by overall employment) over the studied period as shown by Fig. 1 .

In 2001, the average share of entrepreneurs in the working population was approximately $7 \%$; in 2011, this share had increased to nearly $10 \%$. We further observe a highly skewed distribution of entrepreneurs across the 72 labour market regions, ranging from $5 \%$ in the least entrepreneurial region to nearly $15 \%$ in the most entrepreneurial region (Fig. 2).

Figure 3 depicts the how intra- and inter-regional labour mobility has evolved over time. Unsurprisingly, changing employers within labour market regions is a much more

\footnotetext{
${ }^{10}$ We use functional regions (FA-regions), which have been defined by the Swedish Agency for Economic and Regional Growth (Tillväxtverket) as geographical areas in which persons can live and work without lengthy commutes. They thus comprise local labour markets and are delineated based on commuting intensities.
} 
Fig. 1 Average

entrepreneurship rate in the overall population, 2001-2008

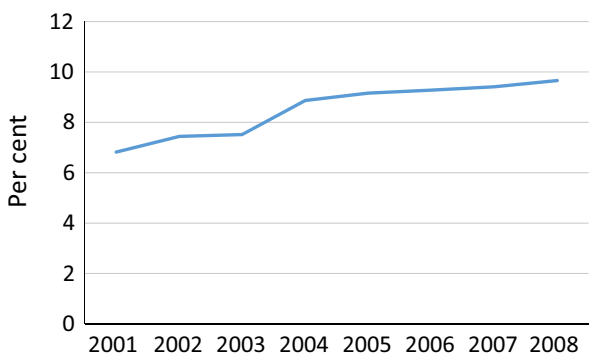

Fig. 2 Entrepreneurship rate distributed across 72 labour market regions, average 2001-2008

Fig. 3 Intra- and inter-regional labour mobility as a percentage of total employment, 2001-2008
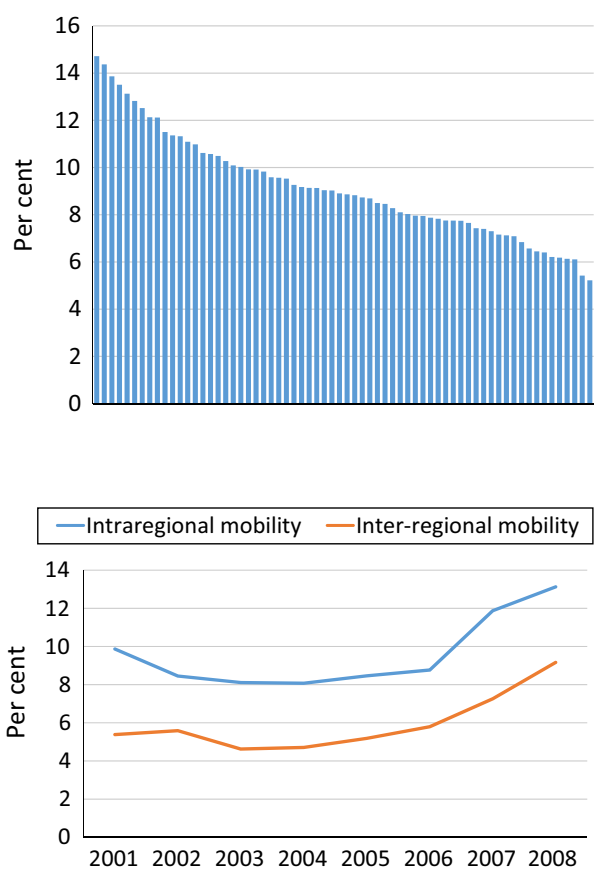

common phenomenon than job switching across regional borders. The decision to begin working in a new region often requires moving to a new residence and that one's spouse also finds a new job in the region. These types of obstacles tend to make inter-regional labour mobility less common than intra-regional mobility. Finally, we observe that both types of labour mobility decreased somewhat in the beginning of the period but exhibited an increasing trend from 2004 onwards.

\subsection{Dependent variable}

The question we seek to answer in this analysis is: to what extent do the knowledge flows caused by labour mobility affect the propensity to start a firm? We argue that the mechanism underlying this effect is the larger local opportunity set that should be available to potential entrepreneurs due to the accumulation of new localized knowledge generated through labour mobility. To isolate this effect, we restrict the entrepreneurial choice to 
individuals who have remained within one labour market region throughout the entire period, which leaves us with a total of 19,599,729 observations. ${ }^{11}$

The binary dependent variable in the econometric analysis is defined as,

$$
y_{i, r, t}=\left\{\begin{array}{cc}
1 & \text { if individual i in region } \mathrm{r} \text { is entrepreneur year } \mathrm{t} \\
0 & \text { otherwise }
\end{array}\right.
$$

where entrepreneurs are defined as business owners and owners of incorporated companies.

\subsection{Labour mobility variables}

We distinguish among three different types of labour mobility depending on whether job switching occurs across regional borders or not and on the direction job switching occurs in the former case. Labour mobility into a region is measured by the number of inward interregional job switchers divided by overall regional employment,

$I N_{r, t}=$

Number of workers starting to work in region $\mathrm{r}$ year $\mathrm{t}$ who worked in another region year $\mathrm{t}-1$

Total employment in region $r$ in year $t$

while the rate of outward inter-regional job switching is defined as,

$O U T_{r, t}=$

Number of workers starting to work in another region year $\mathrm{t}$ who worked in region $\mathrm{r}$ year $\mathrm{t}-1$

Total employment in region $r$ in year $t$

Finally, we define the rate of labour mobility within regional borders as,

WITHIN $_{r, t}=$

Number of workers who switched employer within region $\mathrm{r}$ between year $\mathrm{t}-1$ and year $\mathrm{t}$

Total employment in region $\mathrm{r}$ in year $\mathrm{t}$

\subsection{Control variables}

We include several control variables at the individual level and the regional level in the analysis. Individual level variables include age, age squared, years in education and potential work experience, measured as age minus years in education minus seven. These variables correspond more or less to the standard Mincerian variables used in earnings equations, but we argue that this set of variables should also be relevant for capturing entrepreneurial talent. However, since the variables also explain productivity in a more general sense they will affect both the individual's opportunities as an employee as well as his entrepreneurial opportunities. It is the relative strength of these two effects that determine if the individual will start a firm and become an entrepreneur or if he instead

11 All observations for the Ludvika labour market region in 2007 are excluded from the dataset due to a suspiciously high labour mobility variable. 
Table 1 Descriptive statistics

\begin{tabular}{|c|c|c|c|c|}
\hline & Mean & $\begin{array}{l}\text { Standard } \\
\text { deviation }\end{array}$ & Min & Max \\
\hline \multicolumn{5}{|l|}{ Variables at the individual level } \\
\hline Dummy for entrepreneurship, our dependent variable & 0.085 & 0.28 & 0.0 & 1.0 \\
\hline Nationality (1 Swedish, 0 Foreign) & 0.820 & 0.38 & 0.0 & 1.0 \\
\hline Entrepreneurship experience, dummy & 0.114 & 0.32 & 0.0 & 1.0 \\
\hline Female, dummy & 0.478 & 0.50 & 0.0 & 1.0 \\
\hline Age & 45.3 & 10.6 & 17.0 & 85.0 \\
\hline Number of years in education & 12.1 & 2.41 & 0.0 & 21.0 \\
\hline Experience (age-years of education-7) & 26.1 & 11.0 & 0.0 & 70.0 \\
\hline \multicolumn{5}{|l|}{ Variables at the regional level } \\
\hline $\begin{array}{l}\text { Inter-regional labour mobility in, share of regional } \\
\text { employment }\end{array}$ & 0.060 & 0.02 & 0.0 & 0.30 \\
\hline $\begin{array}{l}\text { Inter-regional labour mobility out, share of regional } \\
\text { employment }\end{array}$ & 0.059 & 0.02 & 0.0 & 0.30 \\
\hline $\begin{array}{l}\text { Intraregional labour mobility, share of regional } \\
\text { employment }\end{array}$ & 0.096 & 0.06 & 0.0 & 0.20 \\
\hline Regional employment & 259,572 & 258,776 & 1004 & 694,645 \\
\hline Regional tertiary education rate & 0.309 & 0.08 & 0.10 & 0.50 \\
\hline Regional density, number of employed per $\mathrm{km}^{2}$ & 37.3 & 25.6 & 0.10 & 67.8 \\
\hline
\end{tabular}

finds it more attractive to work as an employee. Including a squared age variable enables us to capture potential non-linear age effects on entrepreneurship.

We complement the set of variables at the individual level with a dummy variable for native Swedes since previous research has shown that they on average have a lower probability to start a new firm than individuals with a foreign background (Dana 2011). Furthermore, we include a dummy variable for females to control for their lower likelihood of starting a new firm as compared to males (GEM 2014). Finally, we add a dummy variable for previous entrepreneurial experience during the time period 1986-2000. Having started a firm in the past is a strong predictor for future entrepreneurial activity (Davidsson and Honig 2003; Delmar and Davidsson 2000; Farmer et al. 2011) and we therefore expect a positive sign for this variable.

Regional control variables include region size (measured as the total number of individuals employed in the region), regional density (number of employed individuals per square kilometre) and the average level of human capital (tertiary education rate). These variables are meant to capture factors that affect the knowledge stock available to entrepreneurs. The first two variables - regional size and density-facilitate knowledge diffusion and are also associated with the level of knowledge endowment, while the general level of education in the region is more directly related to the generation of new knowledge. Finally, we control for time and industry specific effects that might affect entrepreneurship by including dummy variables. Descriptive statistics for the variables and a correlation matrix are provided in Tables 1 and 2 . 


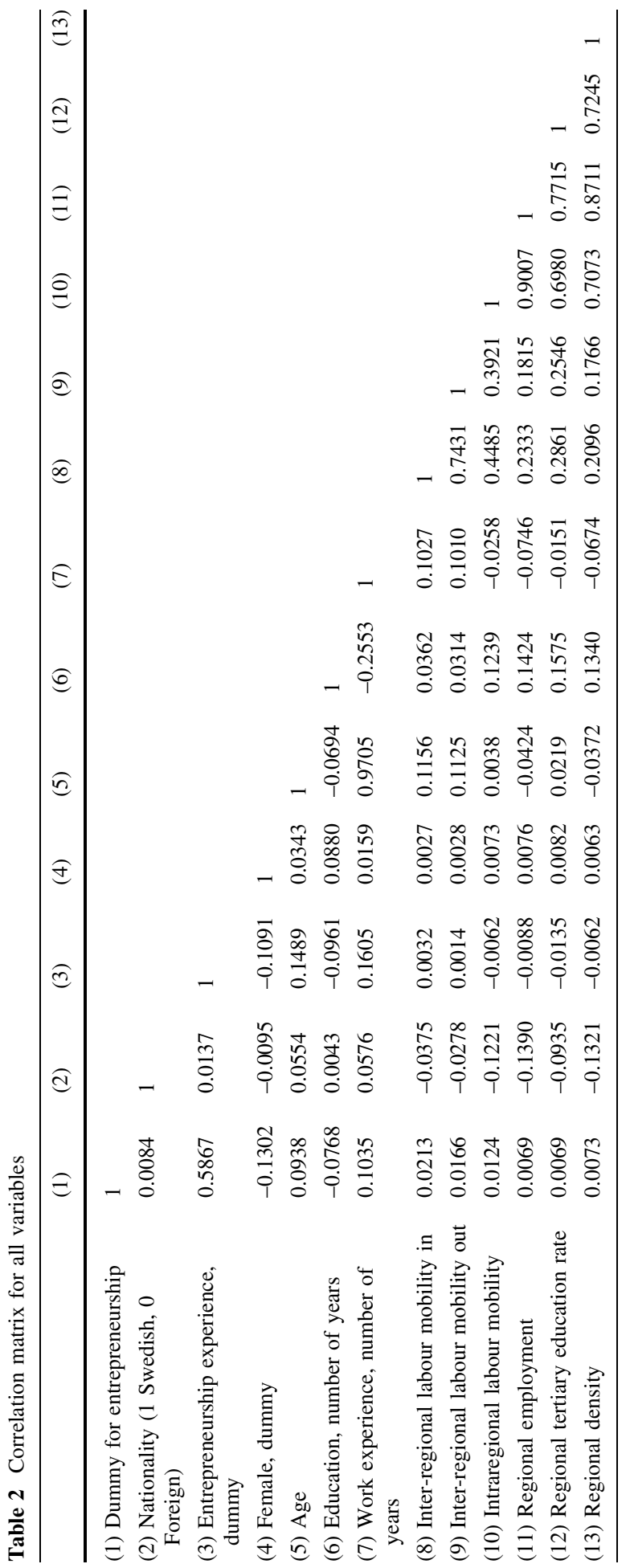


The relationship between labour mobility and entrepreneurship is estimated using an ordinary logistic model with robust standard errors clustered at the individual level. ${ }^{12}$

$$
\begin{gathered}
\operatorname{Pr}\left[y_{i, r, t}=1 \mid \mathbf{V}_{i, r, t}\right]=F\left(\mathbf{V}_{i, r, t}^{\prime} \boldsymbol{\alpha}\right) \\
\mathbf{V}_{i, r, t}^{\prime} \boldsymbol{\alpha}=\alpha_{1} I N_{r, t}+\alpha_{2} \text { OUT }_{r, t}+\alpha_{3} \operatorname{WITHIN~}_{r, t}+\mathbf{x}_{i, r, t}^{\prime} \boldsymbol{\beta}+\mathbf{z}_{r, t}^{\prime} \boldsymbol{\gamma}
\end{gathered}
$$

where we include variables affecting entrepreneurial talent in vector $\mathbf{x}$ and regional control variables in vector $\mathbf{z}$.

\section{Results}

We present four different regression specifications in Table 3, where the first three columns show estimates when each mobility variable is included separately and the final column presents the result when all three mobility variables are included jointly. From Table 2 we know that the mobility variables are somewhat correlated with each other and providing four alternative specifications enables us to assess how potential multicollinearity among the labour mobility variables affects the estimates. ${ }^{13}$ Furthermore, marginal effects are presented in Table 4 in order to assess the economic importance of the estimated effects shown in Table 3.

The first finding that is apparent from the tables is that the average level of regional labour mobility seems to be related to individuals' occupational choices. A higher level of workers switching employers within a region and more workers entering a region both increase the likelihood of entrepreneurship for those currently working as employees in the same region. The effect is highly significant and in line with our expectations, and we contend that this positive effect is at least partially driven by the increased knowledge flows that follow when workers move between employers. The effect is also economically significant as shown by the marginal effects in Table 4. Increasing a region's rate of inward labour mobility or intraregional mobility by $100 \%$ points is associated with an increase in the average individual's probability of starting a new firm by approximately 4-6\% points. To put these numbers into perspective, if the region with the mean level of intraregional labour mobility (9.6\% according to Table 1 ) all else equal saw its share increase to the same level as for the region with the highest share $(20 \%)$, then that would be associated with an increase in the same region's entrepreneurship rate by approximately $0.64 \%$ points. ${ }^{14}$ Given that the average rate of entrepreneurship in the sample is $8.5 \%$ (see

\footnotetext{
12 The data we have at our disposal is a panel where we follow individuals over time. The dependent variable is binary-zero if an individual is working as an employee and one if the individual is an entrepreneur. We have elaborated with a panel logit estimator, but failed to achieve convergence in some cases. Hence, we use the ordinary logit estimator with standard errors clustered at the individual level instead, which we find suitable in this setting. The probit estimator is also plausible when we have a binary dependent variable, but due to the huge amount of data we have access to, this estimator is not always practical to use.

13 By judging from how the estimated coefficients for the mobility variables change across the four different regression specifications in Table 3 we conclude that inward and outward labour mobility are slightly multicollinear while no such tendencies can be found for intraregional labour mobility. Note however that the presence of multicollinearity doesn't render the regression results invalid, but rather suggests that it could be somewhat difficult to disentangle the effects from inward and outward labour mobility from each other on the probability for entrepreneurship.
}

${ }^{14}(0.200-0.096) \times 0.0615 \approx 0.0064$. 
Table 3 Results from the logistic regressions

\begin{tabular}{|c|c|c|c|c|}
\hline & (1) & (2) & (3) & (4) \\
\hline $\begin{array}{l}\text { Inter-regional labour mobility in, share of } \\
\text { regional employment }\end{array}$ & $\begin{array}{l}1.326 * * * \\
(8.58)\end{array}$ & - & - & $\begin{array}{l}0.886^{* * * *} \\
(6.45)\end{array}$ \\
\hline $\begin{array}{l}\text { Inter-regional labour mobility out, share of } \\
\text { regional employment }\end{array}$ & - & $\begin{array}{l}-0.551 * * * \\
(-3.94)\end{array}$ & - & $\begin{array}{l}-1.789 * * * \\
(-15.25)\end{array}$ \\
\hline $\begin{array}{l}\text { Intraregional labour mobility, share of regional } \\
\text { employment }\end{array}$ & - & - & $\begin{array}{l}1.323 * * * \\
(20.76)\end{array}$ & $\begin{array}{l}1.381 * * * \\
(21.26)\end{array}$ \\
\hline Nationality (1 Swedish, 0 Foreign) & $\begin{array}{l}-0.0422 * * * \\
(-6.31)\end{array}$ & $\begin{array}{l}-0.0435 * * * \\
(-6.51)\end{array}$ & $\begin{array}{l}-0.0371 * * * \\
(-5.53)\end{array}$ & $\begin{array}{l}-0.0371 * * * \\
(-5.54)\end{array}$ \\
\hline Entrepreneurship experience, dummy & $\begin{array}{l}3.448 * * * \\
(676.38)\end{array}$ & $\begin{array}{l}3.449 * * * \\
(676.38)\end{array}$ & $\begin{array}{l}3.449 * * * \\
(676.31)\end{array}$ & $\begin{array}{l}3.449 * * * \\
(676.29)\end{array}$ \\
\hline Female, dummy & $\begin{array}{l}-0.498 * * * \\
(-85.95)\end{array}$ & $\begin{array}{l}-0.499 * * * \\
(-85.95)\end{array}$ & $\begin{array}{l}-0.499 * * * \\
(-86.07)\end{array}$ & $\begin{array}{l}-0.499 * * * \\
(-86.08)\end{array}$ \\
\hline Ln (age) & $\begin{array}{l}7.053 * * * \\
(24.84)\end{array}$ & $\begin{array}{l}7.045^{* * * *} \\
(24.81)\end{array}$ & $\begin{array}{l}7.003 * * * \\
(24.68)\end{array}$ & $\begin{array}{l}7.006 * * * \\
(24.69)\end{array}$ \\
\hline $\operatorname{Ln}(\text { age })^{2}$ & $\begin{array}{l}-0.866^{* * * *} \\
(-23.55)\end{array}$ & $\begin{array}{l}-0.865 * * * \\
(-23.53)\end{array}$ & $\begin{array}{l}-0.860 * * * \\
(-23.40)\end{array}$ & $\begin{array}{l}-0.860 * * * \\
(-23.41)\end{array}$ \\
\hline Ln (number of years in education) & $\begin{array}{l}0.192 * * * \\
(15.41)\end{array}$ & $\begin{array}{l}0.192 * * * \\
(15.44)\end{array}$ & $\begin{array}{l}0.190 * * * \\
(15.27)\end{array}$ & $\begin{array}{l}0.190 * * * \\
(15.29)\end{array}$ \\
\hline Ln (experience) & $\begin{array}{l}-0.109 * * * \\
(-8.71)\end{array}$ & $\begin{array}{l}-0.109 * * * \\
(-8.74)\end{array}$ & $\begin{array}{l}-0.107^{* * * *} \\
(-8.56)\end{array}$ & $\begin{array}{l}-0.107 * * * \\
(-8.56)\end{array}$ \\
\hline Ln (regional employment) & $\begin{array}{l}0.0143 * * \\
(2.64)\end{array}$ & $\begin{array}{l}0.0109 * \\
(2.01)\end{array}$ & $\begin{array}{l}-0.00868 \\
(-1.59)\end{array}$ & $\begin{array}{l}-0.0155^{* *} \\
(-2.83)\end{array}$ \\
\hline Regional tertiary education rate & $\begin{array}{l}-0.693 * * * \\
(-11.37)\end{array}$ & $\begin{array}{l}-0.649 * * * \\
(-10.65)\end{array}$ & $\begin{array}{l}-0.948 * * * \\
(-15.20)\end{array}$ & $\begin{array}{l}-0.911 * * * \\
(-14.61)\end{array}$ \\
\hline Regional density, number of employed per $\mathrm{km}^{2}$ & $\begin{array}{l}0.00191 * * * \\
(7.30)\end{array}$ & $\begin{array}{l}0.00219 * * * \\
(8.33)\end{array}$ & $\begin{array}{l}0.00180 * * * \\
(6.83)\end{array}$ & $\begin{array}{l}0.00208 * * * \\
(6.83)\end{array}$ \\
\hline Industry dummies & YES & YES & YES & YES \\
\hline Year dummies & YES & YES & YES & YES \\
\hline Constant & $\begin{array}{l}-16.20 * * * \\
(-30.26)\end{array}$ & $\begin{array}{l}-16.06 * * * \\
(-30.01)\end{array}$ & $\begin{array}{l}-15.82 * * * \\
(-29.57)\end{array}$ & $\begin{array}{l}-15.73 * * * \\
(-29.38)\end{array}$ \\
\hline Number of observations & $19,599,729$ & $19,599,729$ & $19,599,729$ & $19,599,729$ \\
\hline
\end{tabular}

*** $0.1 \%$ significance; $* * 1 \%$ significance; $* 5 \%$ significance. Estimation is by logit regression with cluster standard errors of personal id

descriptive statistics in Table 1), this would on average translate into an increase in entrepreneurship of around $7.5 \%$.

While the rate of labour inflow is positively related to the decision to be an entrepreneur, the opposite effect is found for workers leaving the region. Thus, the results indicate that the potentially positive effect of an extended geographical network that emerges when workers leave a region is smaller than the direct negative effect of having a smaller number of workers within the region.

Turning to the control variables at the individual level; in accordance with our expectation we find that being a native Swede decreases the likelihood of entrepreneurship while having prior entrepreneurial experience is positively associated with the probability of re-entering into entrepreneurship. The reported marginal effect in Table 4 shows that 
Table 4 Marginal effects evaluated at means

\begin{tabular}{|c|c|c|c|c|}
\hline & (1) & (2) & (3) & (4) \\
\hline $\begin{array}{l}\text { Inter-regional labour mobility in, share } \\
\text { of regional employment }\end{array}$ & $\begin{array}{l}0.0591 * * * \\
(8.58)\end{array}$ & - & - & $\begin{array}{l}0.0395 * * * \\
(6.45)\end{array}$ \\
\hline $\begin{array}{l}\text { Inter-regional labour mobility out, share } \\
\text { of regional employment }\end{array}$ & - & $\begin{array}{l}-0.0245^{* * * *} \\
(-3.94)\end{array}$ & - & $\begin{array}{l}-0.0797 * * * \\
(-3.94)\end{array}$ \\
\hline $\begin{array}{l}\text { Intraregional labour mobility, share of } \\
\text { regional employment }\end{array}$ & - & - & $\begin{array}{l}0.0589 * * * \\
(20.74)\end{array}$ & $\begin{array}{l}0.0615^{* * *} \\
(21.24)\end{array}$ \\
\hline Nationality (1 Swedish, 0 Foreign) & $\begin{array}{l}-0.00188 * * * \\
(-6.31)\end{array}$ & $\begin{array}{l}-0.00194 * * * \\
(-6.51)\end{array}$ & $\begin{array}{l}-0.00165^{* * *} \\
(-5.53)\end{array}$ & $\begin{array}{l}-0.00165^{* * * *} \\
(-5.54)\end{array}$ \\
\hline Entrepreneurship experience, dummy & $\begin{array}{l}0.154 * * * \\
(838.02)\end{array}$ & $\begin{array}{l}0.154 * * * \\
(837.92)\end{array}$ & $\begin{array}{l}0.154 * * * \\
(837.78)\end{array}$ & $\begin{array}{l}0.154 * * * \\
(837.80)\end{array}$ \\
\hline Female, dummy & $\begin{array}{l}-0.0222 * * * \\
(-85.55)\end{array}$ & $\begin{array}{l}-0.0222 * * * \\
(-85.56)\end{array}$ & $\begin{array}{l}-0.0222 * * * \\
(-85.67)\end{array}$ & $\begin{array}{l}-0.0222 * * * \\
(-85.68)\end{array}$ \\
\hline Ln (age) & $\begin{array}{l}0.314 * * * \\
(24.80)\end{array}$ & $\begin{array}{l}0.314 * * * \\
(24.77)\end{array}$ & $\begin{array}{l}0.312 * * * \\
(24.63)\end{array}$ & $\begin{array}{l}0.312 * * * \\
(24.64)\end{array}$ \\
\hline $\operatorname{Ln}(\text { age })^{2}$ & $\begin{array}{l}-0.0386^{* * * *} \\
(-23.51)\end{array}$ & $\begin{array}{l}-0.0385 * * * \\
(-23.48)\end{array}$ & $\begin{array}{l}-0.0383^{* * * *} \\
(-23.35)\end{array}$ & $\begin{array}{l}-0.0383 * * * \\
(-23.37)\end{array}$ \\
\hline Ln (number of years in education) & $\begin{array}{l}0.00855^{* * * *} \\
(15.40)\end{array}$ & $\begin{array}{l}0.00857 * * * \\
(15.43)\end{array}$ & $\begin{array}{l}0.00847 * * * \\
(15.26)\end{array}$ & $\begin{array}{l}0.00848 * * * \\
(15.27)\end{array}$ \\
\hline Ln (experience) & $\begin{array}{l}-0.00484 * * * \\
(-8.71)\end{array}$ & $\begin{array}{l}-0.00486^{* * *} \\
(-8.74)\end{array}$ & $\begin{array}{l}-0.00475^{* * *} \\
(-8.56)\end{array}$ & $\begin{array}{l}-0.00476^{* * *} \\
(-8.56)\end{array}$ \\
\hline Ln (regional employment) & $\begin{array}{l}0.000636 * * \\
(2.64)\end{array}$ & $\begin{array}{l}0.000485^{*} \\
(2.01)\end{array}$ & $\begin{array}{l}-0.000387 \\
(-1.59)\end{array}$ & $\begin{array}{l}-0.000692 * * \\
(-2.83)\end{array}$ \\
\hline Regional tertiary education rate & $\begin{array}{l}-0.0309 * * * \\
(-11.37)\end{array}$ & $\begin{array}{l}-0.0289 * * * \\
(-10.65)\end{array}$ & $\begin{array}{l}-0.0422 * * * \\
(-15.20)\end{array}$ & $\begin{array}{l}-0.0406 * * * \\
(-14.61)\end{array}$ \\
\hline $\begin{array}{l}\text { Regional density, number of employed } \\
\text { per } \mathrm{km}^{2}\end{array}$ & $\begin{array}{l}0.0000853 * * * \\
(7.30)\end{array}$ & $\begin{array}{l}0.0000977 * * * \\
(8.33)\end{array}$ & $\begin{array}{l}0.0000802 * * * \\
(6.83)\end{array}$ & $\begin{array}{l}0.0000926 * * * \\
(7.84)\end{array}$ \\
\hline
\end{tabular}

$* * * 0.1 \%$ significance; $* * 1 \%$ significance; $* 5 \%$ significance

having prior entrepreneurship experience increases the average probability of becoming an entrepreneur by $15 \%$ points. Furthermore, the dummy for females is negative and statistically significant, thereby corroborating prior empirical findings. The size of the estimated coefficient indicates that the likelihood of entrepreneurship is on average around $2 \%$ points lower for females as compared to males. An individual's age, education and work experience are all highly significant in explaining the decision to become an entrepreneur. More work experience is negatively related to entrepreneurship, whereas more schooling increases the probability of entrepreneurship. One explanation for the negative effect of being employed for a longer time is the above discussed rigidities characterizing the Swedish labour market that may induce a selection effect (insider-outsider structure). In addition, it could be the case that additional experience increases both the likelihood of finding entrepreneurial opportunities and an individual's employability. If the latter effect is stronger than the former, more experience will reduce the likelihood of choosing an entrepreneurial career. Turning to the regional controls, the negative effects of the average level of education should, for similar reasons as referred to above, be interpreted cautiously. Finally, the region's size has a somewhat ambiguous impact on the decision to 
Table 5 Marginal effects evaluated at different ages, all other variables are at means

\begin{tabular}{llll}
\hline Age & $\begin{array}{l}\text { Inter-regional labour mobility } \\
\text { in, share of regional } \\
\text { employment }\end{array}$ & $\begin{array}{l}\text { Inter-regional labour mobility } \\
\text { out, share of regional } \\
\text { employment }\end{array}$ & $\begin{array}{l}\text { Intraregional labour mobility, } \\
\text { share of regional employment }\end{array}$ \\
\hline 20 & $\begin{array}{l}0.00135 * * * \\
(4.86)\end{array}$ & $\begin{array}{l}-0.00272 * * * \\
(-6.60)\end{array}$ & $\begin{array}{l}0.00210 * * * \\
(6.91)\end{array}$ \\
30 & $\begin{array}{l}0.0130 * * * \\
(6.31)\end{array}$ & $-0.0262^{* * *}$ & $0.0202 * * *$ \\
40 & $\begin{array}{l}0.0416 * * * \\
(6.45)\end{array}$ & $(-13.52)$ & $(17.11)$ \\
50 & $\begin{array}{l}0.0741 * * * \\
(6.43)\end{array}$ & $-0.0839 * * *$ & $0.0648 * * *$ \\
60 & $0.0974 * * *$ & $(-15.18)$ & $(21.08)$ \\
& $(6.45)$ & $(-15.05)$ & $0.115 * * *$ \\
& & $-0.197 * * *$ & $(20.74)$ \\
\end{tabular}

*** $0.1 \%$ significance; $* * 1 \%$ significance; $* 5 \%$ significance

Table 6 Marginal effects for different levels of education, all other variables are at means

\begin{tabular}{llll}
\hline $\begin{array}{l}\text { Number of } \\
\text { years in } \\
\text { education }\end{array}$ & $\begin{array}{l}\text { Inter-regional labour } \\
\text { mobility in, share of regional } \\
\text { employment }\end{array}$ & $\begin{array}{l}\text { Inter-regional labour mobility } \\
\text { out, share of regional } \\
\text { employment }\end{array}$ & $\begin{array}{l}\text { Intraregional labour } \\
\text { mobility, share of regional } \\
\text { employment }\end{array}$ \\
\hline 9 & $\begin{array}{l}0.0384 * * * \\
(6.45)\end{array}$ & $\begin{array}{l}-0.0776 * * * \\
(-15.24)\end{array}$ & $\begin{array}{l}0.0599 * * * \\
(21.22)\end{array}$ \\
12 & $\begin{array}{l}0.0392 * * * \\
(6.45)\end{array}$ & $-0.0792 * * *$ & $0.0612 * * *$ \\
& $0.0397 * * *$ & $(-15.25)$ & $(21.24)$ \\
14 & $(6.45)$ & $(-15.25)$ & $0.0619 * * *$ \\
15 & $0.0399 * * *$ & $-0.0805 * * *$ & $(21.24)$ \\
17 & $(6.45)$ & $(-15.25)$ & $0.0622 * * *$ \\
& $0.0403 * * *$ & $-0.0813 * * *$ & $(21.24)$ \\
20 & $(6.45)$ & $(-15.24)$ & $0.0628 * * *$ \\
& $0.0408 * * *$ & $-0.0823 * * *$ & $(21.23)$ \\
& $(6.45)$ & $(-15.24)$ & $0.0635 * * *$ \\
\end{tabular}

$* * * 0.1 \%$ significance; $* * 1 \%$ significance; $* 5 \%$ significance

become an entrepreneur, while a denser environment seems to be conducive to entrepreneurship. ${ }^{15}$

Tables 5 and 6 report the marginal effects of regional labour mobility on the probability of becoming an entrepreneur evaluated at different ages and education levels, respectively.

Beginning with Table 5, labour mobility tends to be more important for the likelihood of entrepreneurship among older individuals. This could be due to older individuals having larger social networks and therefore a greater likelihood of accessing the larger opportunity

15 Note that regional size and density are highly correlated (0.71 according to Table 2$)$. Excluding the density variable from the regressions causes the impact of regional size to be positive throughout the different specifications. 
set generated by labour mobility. Older individuals can also be expected to have acquired better skills to absorb new knowledge relative to younger individuals who have less experience. On average, the results in Table 5 suggest that the positive effect of interregional and intra-regional labour mobility on the decision to become an entrepreneur is many times larger for those aged 60 years relative to 20 -year-olds. The same conclusion holds for inter-regional labour mobility exiting the region but in this case with a reversed sign. From Table 6, it is evident that the marginal effects become larger when we consider better-educated individuals, but the differences are not as pronounced as those for different ages. This is likely to capture a higher absorptive capacity among those having a higher education.

\section{Concluding remarks}

Entrepreneurship can be conceived as a process driven by the arrival of opportunities. In the current paper, we tested whether labour mobility or, more accurately, the knowledge flows embodied in labour mobility contributes to expanding the opportunity set for potential entrepreneurs. If that was the case, we would expect labour mobility to influence the level of entrepreneurship. In essence, this is equivalent to testing the KSTE of entrepreneurship, developed by Acs et al. (2009).

Employing a unique dataset that captures the individual and regional levels, we provide convincing support for the KSTE of entrepreneurship. Knowledge flows embodied in labour mobility, which can be expected to generate new knowledge and expand the opportunity set, are shown to have a robust and positive impact on entrepreneurship. Both regional inward flows of labour and intra-regional labour mobility increase the probability that individuals will become entrepreneurs, whereas outflows have a negative effect. The control variables generally corroborate the results of previous empirical studies. However, it is worth noting that having previous experience in entrepreneurship has a considerable effect on the propensity to exploit entrepreneurial opportunities due to knowledge flows. An individual's knowledge acquisition capacity thus seems to be partly dependent on previous entrepreneurial experience, which we can regard as a form of entrepreneurial capital (Audretsch et al. 2006).

There are several implications of these findings. First, the results provide support for the KSTE of entrepreneurship, whereby labour mobility is one channel that generates knowledge spillovers and encourages higher levels of entrepreneurship. As shown in Sect. 4, not only the statistical but also the economic effects are quite significant when we examine the relationship between labour mobility, knowledge and entrepreneurship. Second, the results suggest that the functioning of the labour market is more important for regional dynamics and growth than previously thought. Hence, labour market policies that facilitate mobility should be of key concern for regions and countries aiming at higher growth. In addition, other policy measures to improve growth may be hampered by inadequately functioning labour markets. Hence, for a number of countries, not least within the EU, the results may be supportive in designing growth promoting policies.

The interlinks between labour mobility, type of entrepreneurship and growth, and how other growth oriented policy measures and labour market policies interact, seem to be important areas for more in-depth research. In particular, it would be important to investigate whether labour mobility distributed on different types of education impacts growth differently. Given that most countries have their specific labour institutions, a comparative 
analysis at the country level should further contribute to alleviate our understanding of how labour market institutions can be designed to propel growth. This is however tasks for future research and falls outside the current analysis.

Acknowledgments Generous financial support from the Marcus and Marianne Wallenberg's Foundation is gratefully acknowledged.

\section{References}

Acosta, M., Coronado, D., \& Flores, E. (2011). University spillovers and new business location in hightechnology sectors: Spanish evidence. Small Business Economics, 36(3), 365-376.

Acs, Z. J., Braunerhjelm, P., Audretsch, D. B., \& Carlsson, B. (2009). The knowledge spillover theory of entrepreneurship. Small Business Economics, 32(1), 15-30.

Acs, Z. J., \& Sanders, M. (2012). Patents, knowledge spillovers and entrepreneurship. Small Business Economics, 39(4), 801-817.

Acs, Z. J., \& Sanders, M. (2013). Knowledge spillover entrepreneurship in an endogenous growth model. Small Business Economics, 41(4), 775-795.

Aghion, P., Akcigit, U., \& Howitt, P. (2013). What do we learn from Schumpeterian growth theory? CESIS Working Paper No. 298. Stockholm: CESIS - Centre of Excellence for Science and Innovation Studies, Royal Institute of Technology. KTH.

Aghion, P., \& Howitt, P. (1992). A model of growth through creative destruction. Econometrica, 60(2), 323-351.

Aldrich, H. E., \& Zimmer, C. (1986). Entrepreneurship through social networks. In D. L. Sexton \& R. W. Smilor (Eds.), The art and science of entrepreneurship (pp. 3-23). Cambridge: Ballinger.

Andersson, M., \& Hellerstedt, K. (2009). Location attributes and start-ups in knowledge-intensive business sectors. Industry and Innovation, 16(1), 103-121.

Audrestch, D. B., \& Kielbach, M. C. (2007). The theory of knowledge spillover entrepreneurship. Journal of Management Studies, 44(7), 1242-1254.

Audretsch, D. B. (2007). Entrepreneurship capital and economic growth. Oxford Review of Economic Policy, 23(1), 63-78.

Audretsch, D. B., Acs, Z. J., Braunerhjelm, P., \& Carlsson, B. (2012). Growth and entrepreneurship. Small Business Economics, 39(2), 289-300.

Audretsch, D. B., \& Belitski, M. (2013). The missing pillar: The creativity theory of knowledge spillover entrepreneurship. Small Business Economics, 41(4), 819-836.

Audretsch, D. B., Keilbach, M. C., \& Lehmann, E. E. (2006). Entrepreneurship and economic growth. New York: Oxford University Press.

Audretsch, D. B., \& Lehmann, E. (2005). Does the knowledge spillover theory of entrepreneurship hold for regions? Research Policy, 34(8), 1191-1202.

Audretsch, D. B., \& Stephan, P. E. (1999). Knowledge spillovers in biotechnology: Sources and incentives. Journal of Evolutionary Economics, 9(1), 97-107.

Baltzopoulos, A., Braunerhjelm, P., \& Tikoudis, I. (2015). Spin-offs: Why geography matters. Journal of Economic Geography. doi:10.1093/jeg/lbv006.

Batten, D. F., Kobayashi, K., \& Andersson, Å. E. (1989). Knowledge, nodes and networks: An analytical perspective. In Å. E. Andersson, D. F. Batten, \& C. Karlsson (Eds.), Knowledge and industrial organization (pp. 31-46). Heidelberg: Springer.

Baumol, W. J. (1990). Entrepreneurship: Productive, unproductive, and destructive. The Journal of Political Economy, 98(5), 893-921.

Berglann, H., Moen, E., Roed, K., \& Skogstrom, J. F. (2009). Entrepreneurship. Origins and returns. IZA DP No. 4250, Bonn.

Birley, S. (1985). The role of networks in the entrepreneurial process. Journal of Business Venturing, 1(1), $107-117$.

Block, J. H., Thurik, R., \& Zhou, H. (2013). What turns knowledge into innovative products? The role of entrepreneurship and knowledge spillovers. Journal of Evolutionary Economics, 23(4), 693-718.

Braunerhjelm, P. (2011). Entrepreneurship, innovation and economic growth: Interdependencies, irregularities and regularities. In D. B. Audretsch, O. Falck, \& P. Heilbach (Eds.), Handbook of research on innovation and entrepreneurship (pp. 161-213). Cheltenham: Edward Elgar Publishing. 
Braunerhjelm, P., Acs, Z. J., Audretsch, D. B., \& Carlsson, B. (2010). The missing link: Knowledge diffusion and entrepreneurship in endogenous growth. Small Business Economics, 34(2), 105-125.

Braunerhjelm, P., Ding, D., \& Thulin, P. (2014), Does labor mobility foster innovation? The case of Sweden. Mimeo, presented at the Schumpeter Conference, Jena.

Braunerhjelm, P., von Greiff, C., \& Svaleryd, H. (2009). Utvecklingskraft och omställningsförmåga (Development strength and adjustment capacities). Final report from the Secretariat to the Swedish Government's Globalisation Council, Ministry of Education. www.regeringen.se/globaliseringsradet.

Breznits, S. M., \& Feldman, M. P. (2012). The engaged university. The Journal of Technology Transfer, 37(2), 139-157.

Bruton, G. D., Ahlstrom, D., \& Li, H.-L. (2010). Institutional theory and entrepreneurship. Where are we now and where do we need to move in the future? Entrepreneurship Theory and Practice, 34(3), 421-440.

Carlsson, B., Acs, Z. J., Audretsch, D. B., \& Braunerhjelm, P. (2009). Knowledge creation, entrepreneurship, and economic growth: A historical review. Industrial and Corporate Change, 18(6), 1193-1229.

Criaco, G., Minola, T., Migliorini, P., \& Serrarols-Tarrés, C. (2014). To have and have not: Founders' human capital and university start-ups survival. The Journal of Technology Transfer, 39(4), 567-593.

Dana, L.-P. (2011). Ethnic minority entrepreneurship. In L.-P. Dana (Ed.), World encyclopedia of entrepreneurship (pp. 149-169). Cheltenham: Edward Elgar.

Davidsson, P., \& Honig, B. (2003). The role of social and human capital among nascent entrepreneurs. Journal of Business Venturing, 18(3), 301-331.

De Soto, H. (1989). The other path: The invisible revolution in the third world. New York: Harper and Row.

Delmar, F., \& Davidsson, P. (2000). Where do they come from? Prevalence and characteristics of nascent entrepreneurs. Entrepreneurship \& Regional Development, 12(1), 1-23.

Farmer, S. M., Yao, X., \& Kung-Mcintyre, K. (2011). The behavioral impact of entrepreneur identity aspiration and prior entrepreneurial experience. Entrepreneurship Theory and Practice, 35(2), 245-273.

Fritsch, M., \& Aamoucke, R. (2013). Regional public research, higher education, and innovative start-ups: An empirical investigation. Small Business Economics, 41(4), 865-885.

GEM. (2014). Global entrepreneurship monitor. 2014 Global Report, http://www.gemconsortium.org/ report.

Ghio, N., Guerini, M., Lehmann, E., \& Rossi-Lamastra, C. (2015). The emergence of the knowledge spillover theory of entrepreneurship. Small Business Economics, 44(1), 1-18.

Glaeser, E. L., \& Kerr, W. R. (2009). Local industrial conditions and entrepreneurship: How much of the spatial distribution can we explain? Journal of Economics \& Management Strategy, 18(3), 623-663.

Hayek, F. A. (1945). The use of knowledge in society. The American Economic Review, 35(4), 519-530.

Hayter, C. S. (2013). Conceptualizing knowledge-based entrepreneurship networks: Perspectives from the literature. Small Business Economics, 41(4), 899-911.

Henrekson, M. (2005). Entrepreneurship: A weak link in the welfare state? Industrial and Corporate Change, 14(3), 437-467.

Kaiser, U., Kongsted, H., \& Rønde, T. (2015). Does the mobility of R\&D labor increase innovation? Journal of Economic Behavior \& Organization, 110, 91-105.

Karlsson, C., \& Nyström, K. (2008). Knowledge accessibility and new firm formation. CESIS Working Paper No. 70. Stockholm: CESIS-Centre of Excellence for Science and Innovation Studies, Royal Institute of Technology. KTH.

Karnani, F. (2013). The university's unknown knowledge: Tacit knowledge, technology transfer and university spin-offs findings from an empirical study based on the theory of knowledge. The Journal of Technology Transfer, 38(3), 235-250.

Kobayashi, K. (1995). Knowledge network and market structure: An analytical perspective. In D.F. Batten, J. Casti, \& R. Thord (Eds.), Networks in action (pp. 127-158). Heidelberg: Springer.

Koo, J., \& Cho, K.-R. (2011). New firm formation and industry clusters: A case of the drugs industry in the U.S. Growth and Change, 42(2), 179-199.

Lasch, F., Robert, F., \& Le Roy, F. (2013). Regional determinants of ICT new firm formation. Small Business Economics, 40(3), 671-686.

Lazear, E. P., \& Oyer, P. (2012). Personnel economics. In R. Gibbons \& J. Roberts (Eds.), The handbook of organizational economics (pp. 1-8). Princeton: Princeton University Press.

Lindbeck, A., \& Snower, D. J. (1989). Macroeconomic policy and insider power. The American Economic Review, 79(2), 370-376.

Lucas, R. (1988). On the mechanics of economic development. Journal of Monetary Economics, 22, 3-42.

North, D. C. (1990). Institutions, institutional change and economic performance. New York: Cambridge University Press. 
Nyström, K. (2011). Labor mobility and entrepreneurship: Who do new firms employ? CESIS Working Paper No. 250. Stockholm: CESIS—Centre of Excellence for Science and Innovation Studies, Royal Institute of Technology. KTH.

Owen-Smith, J., \& Powell, W. (2006). Accounting for emergence and novelty in Boston and Bay area biotechnology. In P. Braunerhjelm \& M. P. Feldman (Eds.), Cluster genesis. Technology based industrial development. Oxford/New York: Oxford University Press.

Parker, S. (2009). The economics of entrepreneurship. Cambridge/New York, MA: Cambridge University Press.

Plummer, L. A., \& Acs, Z. J. (2014). Localized competition in the knowledge spillover theory of entrepreneurship. Journal of Business Venturing, 29(1), 121-136.

Polanyi, M. (1966). The tacit dimension. London: The University of Chicago Press.

Qian, H., \& Acs, Z. J. (2013). An absorptive capacity theory of knowledge spillover entrepreneurship. Small Business Economics, 40(2), 185-197.

Quimet, P., \& Zarutskie, R. (2014). Who works for start-ups? The relation between firm age, employee age, and growth. Journal of Financial Economics, 112, 386-407.

Romer, P. M. (1986). Increasing returns and long-run growth. The Journal of Political Economy, 94(5), $1002-1037$.

Romer, P. M. (1990). Endogenous technological change. Journal of Political Economy, 98(5), 71-102.

Schumpeter, J. (1911/34). The theory of economic development. Cambridge, MA: Harvard University Press.

Schumpeter, J. (1942). Capitalism, socialism and democracy. New York: Harper and Row.

Shane, S. (2001). Technology regimes and new firm formation. Management Science, 47(9), 1173-1190.

Shane, S., \& Venkataraman, S. (2000). The promise of entrepreneurship as a field of research. Academy of Management Review, 25(1), 217-226.

Solow, R. (1957). Technical change and the aggregate production function. Review of Economics and Statistics, 39(3), 312-320.

Sørensen, J. B., \& Sharkey, A. J. (2014). Entrepreneurship as a mobility process. American Sociological Review, 79(2), 328-349.

Stam, E. (2013). Knowledge and entrepreneurial employees: A country-level analysis. Small Business Economics, 41(4), 887-898.

Steuzer, M., Obschonka, M., Sternberg, R., \& Cantner, U. (2014). Regional characteristics, opportunity perception and entrepreneurial activity. Small Business Economics, 42(2), 221-244.

Swan, T. W. (1956). Economic growth and capital accumulation. Economic Record, 32(2), 334-361.

Szarka, J. (1990). Networking and small firms. International Small Business Journal, 8(2), 10-22.

Van Praag, C. M., \& Versloot, P. H. (2007). What is the value of entrepreneurship? A review of recent research. Small Business Economics, 29(4), 351-382.

Von Hippel, E. (1988). The sources of innovation. New York: Oxford University Press.

Wennberg, K., Wiklund, J., \& Wright, M. (2011). The effectiveness of university spillovers: Performance difference between university spinoffs and corporate spinoffs. Research Policy, 40(8), 1128-1143.

Williamson, O. E. (1971). The vertical integration of production: Market failure considerations. The American Economic Review, 61(2), 112-123.

Zucker, L. G., Darby, M. R., \& Armstrong, J. (1998). Geographically localized knowledge: Spillovers or markets? Economic Inquiry, 36(1), 65-86. 